\title{
EFEKTIVITAS METODE CERAMAH DAN DISKUSI KELOMPOK TERHADAP PENGETAHUAN DAN SIKAP TENTANG KESEHATAN REPRODUKSI PADA REMAJA DI YAYASAN PENDIDIKAN HARAPAN MEKAR MEDAN
}

\author{
Amira Permata Sari Tarigan \\ Jurusan Keperawatan Poltekkes Medan
}

\begin{abstract}
The problems of the adolecent's reproductive health show an escalation year by year. Based on the survey carried out in Yayasan Pendidikan Harapan Mekar Medan in February of 2010, found 4 (four) cases of Unwanted Pregnancy in 2009-2010 and there were 8 (eight) cases of unwanted pregnancy within 5(five) last year (2005 to 2010). One of the factors assumed to be causing of the problem was lack of adolescent's knowledge about reproductive health. This study aimed to analyze the effectiveness of lecturing and group discussion methods on adolecent's knowledge and attitudes regarding to reproductive health in Yayasan Pendidikan Harapan Mekar Medan in 2010. This type of research was the true experimental pretest-posttest control group design. Population were students of the Yayasan Pendidikan Harapan Mekar Medan. Sample of 90 people who were divided into three groups: experimental group I were treated with lecturing method as many as 30 people, experimental group II were treated with group discussions method as many as 30 people and a control group without treatment as many as 30 people. The results showed that the highest mean difference of knowledge score $(6,30)$ occurred in the group treated through extension with group discussion methods with standart deviation of 2,96, while the mean difference of the score in the group treated through extension with lecturing methods was 4,03 with standart deviation of 2,14. In terms of the variable of attitude, the treatment of extension with group discussion methods showed a higher score improvement $(13,60)$ with standart deviation of 7,77 compared to the score improvement of the group treated through extension with lecturing methods which reached 7,87 with standard deviation of 5,73. The result of ANOVA test and Tamhane's T2 test further showed that the group discussion methods was effective in improving the knowledge and attitude about reproductive health among adolescents in Yayasan Pendidikan Harapan Mekar Medan.The health promotor is suggested to applied group discussion method when carrying out the extension on health in order to make the result desired can be optimally achieved.
\end{abstract}

Keywords: methods, knowledge, attitudes, reproductive health

\section{PENDAHULUAN}

\section{Latar Belakang}

Masa remaja adalah masa transisi antara masa kanak-kanak dengan dewasa dan relatif belum mencapai tahap kematangan mental dan sosial sehingga mereka harus menghadapi tekanan-tekanan emosi dan sosial yang saling bertentangan. Banyak sekali life events yang akan terjadi yang tidak saja akan menentukan kehidupan masa dewasa tetapi juga kualitas hidup generasi berikutnya sehingga menempatkan masa ini sebagai masa kritis (Pramono, 2009).

Pembinaan anak remaja merupakan bagian dari pembangunan sumber daya manusia yang menjadi tanggung jawab orang tua, masyarakat, pemerintah dan remaja itu sendiri. Peningkatan kualitas sumber daya manusia dapat dicapai melalui berbagai upaya pada sasaran awal mulai konsepsi sampai sepanjang hidup manusia. Intervensi pada remaja dianggap penting karena remaja merupakan generasi terdepan sebelum menginjak usia paling produktif (Azwar, 2001).

Di Indonesia saat ini 62 juta remaja sedang bertumbuh di tanah air. Artinya, satu dari lima orang Indonesia berada dalam rentang usia remaja. Mereka adalah calon generasi penerus bangsa dan akan menjadi orangtua bagi generasi berikutnya. Tentunya, dapat dibayangkan, betapa besar pengaruh segala tindakan yang mereka lakukan saat ini kelak di kemudian hari tatkala menjadi dewasa dan lebih jauh lagi bagi bangsa di masa depan (Jameela, 2008).

Berdasarkan data BPS kota Medan (2009), jumlah penduduk kota Medan pada pertengahan tahun 2009 adalah 2.121.053 jiwa dan sebesar 30,75\% atau 652.241 jiwa adalah remaja berusia 10-24 tahun. Banyaknya anak yang memasuki usia remaja, telah 
menyebabkan permasalahan kehidupan makin kompleks. Hal ini selain karena masa remaja dihadapkan pada lima transisi kehidupan yakni melanjutkan sekolah, mencari pekerjaan, memulai kehidupan berkeluarga, menjadi anggota masyarakat dan mempraktekkan hidup sehat, anak usia remaja dengan segala karakteristik fisik, sosial psikologisnya dihadapkan pada liberalisasi norma, sikap dan perilaku Kesehatan Reproduksi Remaja yang berkaitan dengan seksualitas, napza dan HIV/AIDS (triad KRR) seiring dengan dimasukinya era globalisasi dengan segala konsekuensi negatifnya. Secara nasional kasus triad KRR dapat terbaca dari pernyataan Kepala Badan Koordinasi Keluarga Berencana Pusat Dr. Sugiri Syarief, MPA bahwa 22,6\% remaja kita adalah penganut seks bebas, dan data dari Departemen Kesehatan RI yang menyatakan bahwa paling tidak sebanyak 8 persen pria berumur 15 - 24 tahun telah menggunakan obat-obatan terlarang dan 3,02 persen dari total pederita HIV/AIDS di Indonesia saat ini adalah remaja umur 15 - 19 tahun serta 54,77\% adalah kelompok usia 20 - 29 tahun (Dawam, 2009).

Salah satu area penting dalam kesehatan remaja adalah kesehatan reproduksi remaja. Perubahan keadaan yang pesat karena urbanisasi, kematangan dini dari fisik remaja, perubahan perilaku, peningkatan penetrasi mass media internasional yang meningkatkan perilaku seksual remaja dan kebijakan yang salah dari para orang tua mengakibatkan timbulnya masalah kesehatan reproduksi remaja (Surjadi, 2001).

Iskandar (1997) mengatakan sebagaimana dikutip oleh Dinas Kesehatan Lampung Selatan (2008) bahwa akhir-akhir ini perilaku seksual di kalangan remaja menjadi popular, hal tersebut dapat dilihat dengan meningkatnya kejadian kehamilan sebelum menikah, perkawinan dini, melahirkan usia muda, aborsi, bahkan penyakit menular seksual. Kehamilan sebelum menikah dan induced aborsi tidak hanya berdampak negatif pada kesehatan remaja tetapi juga menjadi masalah sosial yang berkepanjangan. Pengaruh informasi global (paparan media audio-visual) yang semakin mudah diakses justru memancing remaja untuk mengadaptasi kebiasaan-kebiasaan tidak sehat seperti merokok, minum minuman beralkohol, penyalahgunaan obat dan suntikan terlarang, perkelahian antar remaja atau tawuran.

$$
\text { Data GOI dan UNICEF (2000) dalam }
$$

Wiknjosastro (2006) menunjukkan bahwa angka pernikahan dini (menikah sebelum berusia 16 tahun) hampir dijumpai di seluruh propinsi di Indonesia. Sekitar $10 \%$ remaja putri melahirkan anak pertamanya pada usia 15 - 19 tahun. Kehamilan remaja akan meningkatkan risiko kematian dua hingga empat kali lebih tinggi dibandingkan perempuan yang hamil pada usia lebih dari 20 tahun. Demikian juga dengan risiko kematian bayi, $30 \%$ lebih tinggi pada ibu usia remaja, dibandingkan pada bayi yang dilahirkan oleh ibu usia 20 tahun atau lebih.

BKKBN (2009) mengumumkan hasil survei yang dilakukan oleh sebuah lembaga survei yang mengambil sampel di 33 propinsi di Indonesia pada tahun 2008 sebanyak $63 \%$ remaja SMP dan SMA di Indonesia pernah berhubungan sex, $21 \%$ diantaranya melakukan aborsi. Angka ini naik dibandingkan dengan tahun-tahun sebelumnya, berdasarkan penelitian 20052006 di kota-kota besar mulai Jabotabek, Medan, Bandung, Surabaya dan Makassar ditemukan sekitar 47\% hingga 54\% remaja mengaku melakukan hubungan sex sebelum menikah. Data dari Depkes RI (2008) sebagaimana disampaikan oleh BKKBN (2009) juga menyebutkan bahwa dari 15.210 penderita AIDS atau orang yang hidup dengan HIV/AIDS $54 \%$ adalah remaja.

Remaja Indonesia masih minim mendapatkan pengetahuan tentang seksualitas dan kesehatan reproduksi, karena untuk penyampaian informasi mengenai hal itu masih dianggap tabu. Selain itu, lebih dari $80 \%$ remaja merasa lebih nyaman membicarakan masalah seksual dengan teman. Sehingga tidak menutup kemungkinan informasi yang mereka terima masih simpang siur. Padahal jika mereka tahu risiko dari berhubungan seksual pranikah, angka-angka tersebut seharusnya bisa lebih ditekan (Az Zahra, 2010).

Berdasarkan Survei Kesehatan Reproduksi Remaja Indonesia (SKRRI) tahun 2002-2003, sebanyak $2 \%$ remaja putri dan $28 \%$ remaja putra tidak mengerti tanda perubahan fisik apapun dari lawan jenisnya. Kurangnya pengetahuan tentang biologi dasar pada remaja mencerminkan kurangnya pengetahuan tentang risiko yang berhubungan dengan tubuh mereka dan cara menghindarinya (Pinem, 2009).

Sekolah sebagai lingkungan sekunder setelah keluarga merupakan tempat yang efektif untuk pendidikan kesehatan reproduksi bagi remaja yang umumnya masih berstatus sebagai pelajar dan mempunyai peranan yang cukup besar di dalam pelaksanaan program penyuluhan kesehatan reproduksi remaja, karena pendidikan tentang kesehatan reproduksi belum masuk di kurikulum mata pelajaran SMU negeri mau pun swasta. Mata pelajaran biologi yang mencakup organ tubuh manusia yang anak didik dapatkan di sekolah-sekolah tidak menerangkan secara luas tumbuh kembang remaja pada saat di SMU (Depkes RI, 2002).

Yayasan pendidikan Harapan Mekar Medan adalah salah satu lembaga pendidikan yang mengelola 4 (empat) jenis jenjang pendidikan yaitu : SMP, SMA, STM dan SMEA, dimana siswa yang berada pada jenjang pendidikan tersebut semuanya adalah berada dalam katagori usia remaja. Berdasarkan survei pendahuluan yang dilakukan, pada Tahun Ajaran ini (2011-2012) terdapat kasus siswa terpaksa putus sekolah karena harus menikah pada usia dini yang disebabkan oleh terjadinya kehamilan tidak diinginkan (KTD), yaitu pada siswa STM sebanyak 1 (satu) orang, siswi SMEA sebanyak 2 (dua) orang dan siswi SMA 1 (satu) orang, dalam kurun waktu 5 (tahun) terakhir ( 2006 s/d 2011) terdapat sebanyak 8 (delapan) orang siswa yang putus sekolah karena KTD dan pernikahan 
di usia dini. Berdasarkan wawancara yang dilakukan pada 10 (sepuluh) orang siswa di Yayasan Pendidikan Harapan Mekar, 8 orang $(80 \%)$ mengatakan tidak mengerti tentang kesehatan reproduksi dan 2 orang (20\%) mengatakan mengerti tentang kesehatan reproduksi tetapi tidak dapat memberikan penjelasan ketika ditanya tentang kesehatan reproduksi. Mereka juga mengatakan sebelumnya belum pernah dilakukan penyuluhan tentang kesehatan reproduksi di Yayasan Pendidikan Harapan Mekar Medan.

Mengingat masih banyaknya pelajar yang belum mengerti tentang kesehatan reproduksi, sangatlah penting untuk dilakukan penyuluhan dengan harapan dapat mengubah pengetahuan dan sikap tentang kesehatan reproduksi pada remaja, dalam hal ini adalah pelajar di Yayasan Pendidikan Harapan Mekar Medan menjadi lebih baik.

Ada beberapa metode yang dapat digunakan dalam melakukan penyuluhan antara lain metode ceramah, diskusi kelompok, curah pendapat, panel, bermain peran, demonstrasi, simposium dan seminar, dimana masing-masing metode mempunyai kelebihan dan kelemahan (Effendi, 1998).

Alternatif metode yang dapat dipergunakan pada penyuluhan kesehatan reproduksi remaja adalah metode ceramah dan metode diskusi kelompok. Metode ceramah, selain sederhana juga efektif dalam upaya penyampaian informasi secara cepat kepada kelompok sasaran yang cukup besar, sedangkan metode diskusi kelompok dapat digunakan untuk penyampaian informasi dengan lebih memberikan kesempatan pada siswa untuk mengumpulkan pendapat, membuat kesimpulan atau menyusun berbagai alternatif pemecahan masalah (Sofa, 2008a).

Berdasarkan latar belakang tersebut, maka dirasa perlu untuk melakukan penelitian tentang "Efektifitas metode ceramah dan diskusi kelompok terhadap peningkatan pengetahuan dan sikap tentang kesehatan reproduksi pada remaja di Yayasan Pendidikan Harapan Mekar Medan”.

\section{Permasalahan}

Bagaimana efektifitas metode ceramah dan diskusi kelompok terhadap peningkatan pengetahuan dan sikap tentang kesehatan reproduksi pada remaja di Yayasan Pendidikan Harapan Mekar Medan”.

\section{Tujuan Penelitian}

Menganalisis efektifitas metode ceramah dan diskusi kelompok terhadap peningkatan pengetahuan dan sikap tentang kesehatan reproduksi pada remaja di Yayasan Pendidikan Harapan Mekar Medan.

\section{Hipotesis}

1. Metode diskusi kelompok lebih efektif dibanding metode ceramah dalam meningkatkan pengetahuan tentang kesehatan reproduksi pada remaja di Yayasan Pendidikan Harapan Mekar Medan.
2. Metode diskusi kelompok lebih efektif dibanding metode ceramah dalam meningkatkan sikap tentang kesehatan reproduksi pada remaja di Yayasan Pendidikan Harapan Mekar Medan.

\section{METODE PENELITIAN}

\section{Jenis Penelitian}

Jenis penelitian ini adalah true eksperimental dengan rancangan pretest-posttest control group design. Dalam design ini terdapat tiga kelompok yang masingmasing dipilih secara random (R). Kelompok pertama diberi perlakuan yaitu penyuluhan dengan metode ceramah (X1), kelompok kedua diberi perlakuan berupa penyuluhan dengan metode diskusi kelompok (X2) dan kelompok ketiga tidak diberi perlakuan (kelompok kontrol).

\section{Lokasi dan Waktu Penelitian}

Penelitian ini dilaksanakan di Yayasan Pendidikan Harapan Mekar Medan yang terletak di Kelurahan Rengas Pulau Kecamatan Medan Marelan Kota Medan pada bulan Agustus sampai dengan Nopember 2011.

\section{Populasi dan Sampel \\ 3.1 Populasi}

Populasi dalam penelitian ini adalah remaja yang berstatus sebagai pelajar kelas I dan kelas II pada Yayasan Pendidikan Harapan Mekar Medan yang berjumlah 1.350 orang.

\subsection{Sampel}

Sampel dihitung dengan menggunakan rumus besar sampel untuk uji hipotesis data kontinu. Dengan menggunakan taraf kemaknaan $5 \%$, kekuatan uji $90 \%$, standar deviasi skor pengetahuan dan sikap masing-masing 4,37 dan 9,56 serta perbedaan skor pengetahuan dan sikap sebelum dan sesudah intervensi sebesar 4,00 dan 9,00, diperoleh besar sampel masing-masing kelompok sebanyak 30 orang siswa, sehingga besar sampel seluruhnya adalah 90 orang siswa. Pengambilan sampel dilakukan secara acak dengan menggunakan tabel random.

\section{Metode Pengumpulan Data}

Alat pengumpul data dalam penelitian ini adalah kuesioner terstruktur yang berisi sejumlah pertanyaan yang diisi oleh responden

Prosedur kegiatan penelitian yang dilakukan meliputi beberapa tahapan yaitu :

\subsection{Tahap Persiapan}

Di tahapan ini peneliti melakukan pengurusan perizinan ke lokasi penelitian. Melakukan pengumpulan data awal yang diperkirakan akan diperoleh dari berbagai sumber data yang terpercaya seperti Ketua Yayasan dan Kepala Sekolah di Yayasan Pendidikan Harapan Mekar Medan. 


\subsection{Tahap Pelaksanaan}

Siswa yang terpilih sebagai sampel yang berjumlah 90 orang kemudian dibagi secara acak menjadi 3 kelompok sampel yaitu ; kelompok eksperimen I, kelompok eksperimen II dan kelompok kontrol. Selanjutnya ketiga kelompok ditempatkan di kelas yang berbeda untuk dilakukan pre-test. Kemudian pada kelompok I (kelompok eksperimen I) diberikan penyuluhan tentang kesehatan reproduksi remaja dengan metode ceramah yang disampaikan oleh peneliti dalam waktu 90 menit. Pada kelompok II (kelompok eksperimen II) diberikan pembelajaran tentang kesehatan reproduksi remaja dengan metode diskusi kelompok. Pada kelompok eksperimen II ini, responden dibagi menjadi 5 kelompok kecil yang beranggotakan 6 orang, dimana masing-masing kelompok akan dipimpin oleh seorang pemimpin diskusi yang dipilih dengan cara kesepakatan bersama antara fasilitator dan responden, selanjutnya fasilitator memberikan arahan kepada seluruh kelompok tentang prosedur yang akan dilakukan dan kemudian memberikan materi dan kuis tentang kesehatan reproduksi remaja kepada masing-masing kelompok serta memberi tugas kepada tiap kelompok untuk menjawab pertanyaan yang terdapat dalam kuis dengan cara berdiskusi dalam waktu 90 menit dan menyerahkan hasil diskusi kepada fasilitator, sedangkan kelompok III (kelompok kontrol) tidak diberi perlakuan. Setelah selesai dilakukan penyuluhan, selanjutnya pada ketiga kelompok langsung dilakukan post test pada hari itu juga.

\section{Metode Analisis Data}

1. Analisis Univariat, adalah analisis yang dilakukan untuk melihat gambaran tiap-tiap variabel atau disebut juga analisis deskriptif. Analisis ini juga digunakan untuk melihat normalitas data.

2. Analisis Bivariat, untuk melihat hubungan antara dua variabel. Untuk melihat hubungan antara umur, jenis kelamin, status sosial ekonomi dengan pengetahuan dan sikap siswa digunakan uji t, sedangkan untuk melihat hubungan pola asuh orang tua, suku dan metode penyuluhan terhadap pengetahuan dan sikap tentang kesehatan reproduksi digunakan uji anova dan dilanjutkan dengan analisis komparasi ganda menggunakan Tamhane's T2.

3. Analisis Multivariat, untuk melihat hubungan antara dua variabel independen atau lebih dengan satu atau lebih variabel dependen secara bersamaan. Untuk melihat hubungan antara varibel umur, jenis kelamin, status sosial ekonomi dan pola asuh orang tua secara bersamaan terhadap pengetahuan dan sikap tentang kesehatan reproduksi remaja digunakan regresi linier ganda. Namun dalam penelitian ini tidak dilakukan analisis multivariat karena pada analisis bivariat nilai P seluruh variabel $>0,25$.

\section{HASIL PENELITIAN}

\section{Karakteristik Responden}

Untuk melihat adanya perbedaan karakteristik responden pada ketiga kelompok dilakukan uji Chi- square. Hasil penelitian menunjukkan bahwa tidak terdapat perbedaan kelompok umur $(\mathrm{P}=0,296)$, sosial ekonomi $(\mathrm{P}=0,955)$, jenis kelamin $(\mathrm{P}=0,839)$ dan pola asuh orang tua $(\mathrm{P}=0,888)$ pada ketiga kelompok.

Gambaran karakteristik responden dapat dilihat pada tabel berikut:

Tabel 1. Gambaran Karakteristik Responden

\begin{tabular}{lccccccc}
\hline Karakteristik & $\begin{array}{c}\text { Kelompok } \\
\text { Eksperimen I }\end{array}$ & $\begin{array}{c}\text { Kelompok } \\
\text { Eksperimen II }\end{array}$ & \multicolumn{2}{c}{$\begin{array}{c}\text { Kelompok } \\
\text { Kontrol }\end{array}$} & P Value \\
\cline { 2 - 7 } & $\mathbf{N}$ & $\mathbf{\%}$ & $\mathbf{n}$ & $\mathbf{\%}$ & $\mathbf{n}$ & $\mathbf{\%}$ & \\
\hline Umur & & & & & & & $\mathbf{0 , 2 9 6}$ \\
$14-15$ tahun & 12 & 40,0 & 12 & 40,0 & 7 & 23,3 & \\
$16-18$ tahun & 18 & 60,0 & 18 & 60,0 & 23 & 76,7 & \\
& & & & & & & \\
Sosial & & & & & & & $\mathbf{0 , 9 5 5}$ \\
Ekonomi & 11 & 36,7 & 12 & 40,0 & 12 & 40,0 & \\
Sosek Rendah & 19 & 63,3 & 18 & 60,0 & 18 & 60,0 & \\
Sosek Tinggi & & & & & & & \\
& & & & & & & $\mathbf{0 , 8 3 9}$ \\
Jenis Kelamin & & & & & & & \\
$\quad$ Laki-laki & 14 & 46,7 & 16 & 53,3 & 14 & 46,7 & \\
$\quad$ Perempuan & 16 & 53,3 & 14 & 46,7 & 16 & 53,3 & \\
& & & & & & & $\mathbf{0 , 8 8 8}$ \\
Pola Asuh & & & & & & & \\
$\quad$ Demokratis & 24 & 80,0 & 23 & 76,7 & 24 & 80,0 & \\
$\quad$ Otoriter & 4 & 13,3 & 2 & 6,7 & 2 & 6,7 & \\
$\quad$ Permisif & 2 & 6,7 & 5 & 16,6 & 4 & 13,3 & \\
& & & & & & &
\end{tabular}

Dari tabel di atas terlihat bahwa variabel umur dibagi menjadi dua kelompok dengan nilai median sebagai titik potong (cut off point) karena variabel ini berdistribusi tidak normal. Nilai minimum umur responden adalah 14 tahun dan maksimum 18 tahun. Umur responden pada kelompok ekperimen I memiliki distribusi yang sama dengan kelompok eksperimen II yaitu umur 14-15 tahun sebanyak 12 orang $(40 \%)$ dan 16-18 sebanyak 18 orang $(60 \%)$ sedangkan pada kelompok kontrol umur 14-15 tahun sebanyak 7 orang $(23,3 \%)$ dan $16-18$ tahun sebanyak 23 orang $(76,7 \%)$.

Penghasilan orang tua yang merupakan indikator dari status sosial ekonomi responden dibagi menjadi dua kelompok dengan titik potongnya adalah nilai garis kemiskinan untuk Sumatera Utara sebesar Rp. 222.898 per kapita per bulan (BPS, 2010). Penghasilan di bawah garis kemiskinan dikatagorikan ke dalam kelompok sosial ekonomi rendah dan penghasilan di atas garis kemiskinan dikatagorikan ke dalam kelompok sosial ekonomi tinggi. Pada kelompok eksperimen I sebanyak 11 responden (36,7\%) merupakan kelompok sosial ekonomi rendah dan sebanyak 19 orang $(63,3 \%)$ berstatus sosial ekonomi tinggi. Pada kelompok eksperimen II sebanyak 12 reponden $(40,0 \%)$ termasuk dalam katagori sosial ekonomi rendah dan sebanyak 18 responden $(60 \%)$ termasuk sosial ekonomi tinggi. Demikian juga pada ada kelompok kontrol sama dengan kelompok eksperimen II.

Jumlah siswa laki-laki pada kelompok eksperimen $\mathrm{I}=$ 14 orang $(46,7 \%)$, perempuan $=16$ orang $(53,3 \%)$. Pada kelompok eksperimen II jumlah siswa laki-laki $=$ 16 orang $(53,3 \%)$ dan jumlah perempuan $=14$ orang 
(46,7 \%). Sedangkan jumlah siswa laki-laki pada kelompok kontrol $=14$ orang $(46,7 \%)$ dan jumlah perempuan $=16$ orang $(53,3 \%)$.

Tipe pola asuh orang tua terbanyak pada kelompok eksperimen I adalah demokratis 24 orang $(80,0 \%)$, sedangkan otoriter 4 orang $(13,3 \%)$ dan permisif sebanyak 2 orang $(6,7 \%)$. Demikian juga pada kelompok eksperimen II, demokratis adalah tipe pola asuh yang terbanyak yaitu 23 orang $(76,7 \%)$ sedangkan otoriter sebanyak 2 orang $(6,7 \%)$ dan permisif sebanyak 5 orang $(16,6 \%)$. Dan tipe pola asuh demokratis juga merupakan tipe pola asuh orang tua terbanyak pada kelompok kontrol yaitu sebanyak 24 orang $(80,0 \%)$ sedangkan otoriter hanya 2 orang $(6,7 \%)$ dan permisif sebanyak 8 orang $(13,3 \%)$.

\section{Gambaran Pengetahuan dan Sikap Siswa tentang Kesehatan Reproduksi}

Indikator pengetahuan dan sikap adalah hasil perolehan informasi dari keseluruhan pertanyaan pada kuesioner tentang pengetahuan dan sikap tentang kesehatan reproduksi remaja. Dari hasil penelitian diperoleh rerata skor pengetahuan responden sebelum perlakuan pada kelompok eksperimen $\mathrm{I}=8,83$ dengan standar deviasi 2,61 dan skor sesudah perlakuan = 12,87 dengan standar deviasi 2,35. Pada kelompok eksperimen II skor pengetahuan sebelum perlakuan = 8,13 dengan standar deviasi 3,06 dan skor sesudah perlakuan $=14,43$ dengan standar deviasi 1,76. Pada kelompok kontrol skor pengetahuan sebelum perlakuan $=8,10$ dengan standar deviasi 3,32 dan skor sesudah perlakuan = 8,30 dengan standar deviasi 3,52.

Skor sikap responden pada kelompok eksperimen I sebelum perlakuan $=69,07$ dengan standar deviasi 6,51 dan skor sesudah perlakuan = 78,20 dengan standar deviasi 6,47. Pada kelompok eksperimen II skor sikap sebelum perlakuan $=66,07$ dengan standar deviasi 9,49 dan skor sesudah perlakuan $=79,67$ dengan standar deviasi 5,79. Pada kelompok kontrol skor sikap sebelum perlakuan $=66,10$ dengan standar deviasi 9,42 dan skor sesudah perlakuan = 67,17 dengan standar deviasi 9,18. Gambaran pengetahuan dan sikap responden sebelum dan sesudah perlakuan dapat dilihat pada Tabel 2.
Tabel 2 Gambaran Skor Pengetahuan dan Sikap Responden Sebelum dan Sesudah Perlakuan

\begin{tabular}{lcc}
\hline Variabel & $\begin{array}{c}\text { Sebelum } \\
\text { Perlakuan }\end{array}$ & $\begin{array}{c}\text { Sesudah } \\
\text { Perlakuan }\end{array}$ \\
\cline { 2 - 3 } & $\overline{\mathbf{x}} \pm \mathbf{s d}$ & $\overline{\mathbf{x}} \pm \mathbf{s d}$ \\
\hline Pengetahuan & & \\
Ceramah & $8,83 \pm 2,61$ & $12,87 \pm 2,35$ \\
$\quad$ Diskusi Kelompok & $8,13 \pm 3,06$ & $14,43 \pm 1,76$ \\
Kontrol & $8,10 \pm 3,32$ & $8,30 \pm 3,52$
\end{tabular}

Sikap

$\begin{array}{lll}\text { Ceramah } & 69,07 \pm 6,51 & 78,20 \pm 6,47 \\ \text { Diskusi Kelompok } & 66,07 \pm 9,49 & 79,67 \pm 5,79 \\ \text { Kontrol } & 66,10 \pm 9,42 & 67,17 \pm 9,18\end{array}$

Berdasarkan perolehan skor pengetahuan dan sikap siswa tentang kesehatan reproduksi, selanjutnya variabel pengetahuan dibagi menjadi tiga katagori yaitu baik, sedang dan kurang, sedangkan variabel sikap dibagi menjadi dua katagori yaitu positif dan negatif.

Sebelum perlakuan pada kelompok eksperimen I, siswa yang berpengetahuan baik sebanyak 5 orang $(16,7 \%)$, sedang 23 orang $(76,7 \%)$ dan kurang 2 orang $(6,6 \%)$, siswa yang bersikap positif sebanyak 19 orang $(63,3 \%)$ dan negatif 11 orang $(36,7 \%)$, sesudah perlakuan siswa yang berpengetahuan baik 5 orang $(16,7 \%)$, sedang 24 orang $(80 \%)$ dan kurang 1 orang $(3,3 \%)$, siswa yang bersikap positif 29 orang $(96,7 \%)$ dan negatif 1 orang $(3,3 \%)$.

Pada kelompok eksperimen II, sebelum perlakuan siswa yang berpengetahuan baik sebanyak 6 orang $(20 \%)$, sedang 19 orang $(63,3 \%)$ dan kurang 5 orang $(16,7 \%)$, siswa yang bersikap positif sebanyak 16 orang $(53,3 \%)$ dan negatif 14 orang $(46,7 \%)$, sesudah perlakuan siswa yang berpengetahuan baik sebanyak 7 orang $(23,3 \%)$, sedang 23 orang $(76,7 \%)$, siswa yang bersikap positif 28 orang $(93,3 \%)$ dan negatif 2 orang $(6,7 \%)$.

Pada kelompok kontrol sebelum perlakuan siswa yang berpengetahuan baik sebanyak 6 orang (20\%), sedang 18 orang (60\%), kurang 6 orang (20\%), siswa yang bersikap positif 16 orang $(53,3 \%)$ dan negatif sebanyak 14 orang $(46,7 \%)$. Sesudah perlakuan, siswa yang berpengetahuan sedang dan kurang masingmasing sebanyak 15 orang (50\%), demikian juga pada sikap positif dan negatif masing-masing sebanyak 15 orang (50\%). Gambaran Katagori pengetahuan dan sikap siswa dapat dilihat pada tabel berikut:

Tabel 3. Gambaran Katagori Pengetahuan dan Sikap Responden Sebelum dan Sesudah Perlakuan

\begin{tabular}{|c|c|c|c|c|c|c|c|c|c|c|c|c|}
\hline \multirow{3}{*}{ Variabel } & \multicolumn{4}{|c|}{ Ceramah } & \multicolumn{4}{|c|}{ Diskusi Kelompok } & \multicolumn{4}{|c|}{ Kontrol } \\
\hline & \multicolumn{2}{|c|}{ Pre } & \multicolumn{2}{|c|}{ Post } & \multicolumn{2}{|c|}{ Pre } & \multicolumn{2}{|c|}{ Post } & \multicolumn{2}{|c|}{ Pre } & \multicolumn{2}{|c|}{ Post } \\
\hline & $\mathrm{n}$ & $\%$ & $\mathrm{n}$ & $\%$ & $\mathrm{n}$ & $\%$ & $\mathrm{n}$ & $\%$ & $\mathrm{n}$ & $\%$ & & $\%$ \\
\hline \multicolumn{13}{|l|}{ Pengetahun } \\
\hline Baik & 5 & 16,7 & 5 & 16,7 & 6 & 20,0 & 7 & 23,3 & 6 & 20,0 & - & - \\
\hline Sedang & 23 & 76,7 & 24 & 80,0 & 19 & 63,3 & 23 & 76,7 & 18 & 60,0 & 15 & 50,0 \\
\hline Kurang & 2 & 6,6 & 1 & 3,3 & 5 & 16,7 & - & - & 6 & 20,0 & 15 & 50,0 \\
\hline \multicolumn{13}{|l|}{ Sikap } \\
\hline Positif & 19 & 63,3 & 29 & 96,7 & 16 & 53,3 & 28 & 93,3 & 16 & 53,3 & 15 & 50,0 \\
\hline Negatif & 11 & 36,7 & 1 & 3,3 & 14 & 46,7 & 2 & 6,7 & 14 & 46,7 & 15 & 50,0 \\
\hline
\end{tabular}


3. Hubungan Metode Penyuluhan dengan Pengetahuan dan Sikap Siswa tentang Kesehatan Reproduksi

\subsection{Hubungan Metode Penyuluhan dengan} Pengetahuan Siswa

Untuk menilai apakah ada hubungan metode penyuluhan dengan pengetahuan siswa tentang kesehatan reproduksi dilakukan dengan cara melihat perbedaaan rerata selisih skor pengetahuan sebelum dan sesudah perlakuan. Hasil penelitian menunjukkan bahwa rerata selisih skor pengetahuan pada kelompok eksperimen $\mathrm{I}=4,03$ dengan standar deviasi $=2,14$, rerata pada kelompok eksperimen II $=6,30$ dengan standar deviasi $=2,96$ dan rerata selisih skor pengetahuan pada kelompok kontrol $=0,20$ dengan standar deviasi $=1,65$. Distribusi rerata selisih skor pengetahuan siswa dapat dilihat pada Tabel di bawah ini :

Tabel 4.Distribusi Rerata Selisih Skor Pengetahuan Siswa

\begin{tabular}{lcccc}
\hline \multicolumn{1}{c}{ Metode } & Mean & SD & $\mathbf{9 5 \%} \boldsymbol{C I}$ & $\begin{array}{c}\mathbf{P} \\
\text { Value }\end{array}$ \\
\hline Ceramah & 4,03 & 2,14 & $3,23-4,83$ & 0,001 \\
Diskusi Kelompok & 6,30 & 2,96 & $5,19-7,41$ & \\
Tanpa Perlakuan & 0,20 & 1,65 & $-0,42-0,82$ & \\
\hline
\end{tabular}

Berdasarkan uji anova menunjukkan bahwa terdapat perbedaan rerata skor pengetahuan di antara tiga kelompok dengan nilai $\mathrm{P}=0,001$. Untuk melihat perbedaan pada masing-masing kelompok dilanjutkan dengan uji Tamhane (T2) karena Levene test menunjukkan bahwa data pada ketiga kelompok memilki varians yang berbeda $(\mathrm{P}=0,000)$. Hasil uji lanjut dengan Tamhane (T2) menunjukkan terdapat perbedaan yang bermakna pada rerata selisih skor pengetahuan siswa antara kelompok eksperimen I dengan kelompok eksperimen II $(\mathrm{P}=0,004)$. Hal ini berarti terdapat pengaruh metode penyuluhan terhadap pengetahuan siswa tentang kesehatan reproduksi. Perlakuan penyuluhan dengan metode diskusi kelompok merupakan metode yang mendapat skor tertinggi dengan nilai rerata 6,3 .

\subsection{Hubungan Metode Penyuluhan dengan Sikap Siswa}

Untuk menilai apakah ada hubungan metode penyuluhan dengan sikap siswa tentang kesehatan reproduksi dilakukan dengan cara melihat perbedaaan rerata selisih skor sikap sebelum dan sesudah perlakuan. Hasil penelitian menunjukkan bahwa rerata selisih skor sikap pada kelompok eksperimen $\mathrm{I}=9,13$ dengan standar deviasi $=4,61$, rerata pada kelompok eksperimen $\mathrm{II}=13,60$ dengan standar deviasi $=7,77$ dan rerata selisih skor sikap pada kelompok kontrol $=$ 1,07 dengan standar deviasi $=2,27$. Distribusi rerata selisih skor sikap siswa dapat dilihat pada tabel berikut:
Tabel 5. Distribusi Rerata Selisih Skor Sikap Siswa

\begin{tabular}{lcccc}
\multicolumn{1}{c}{ Metode } & Mean & SD & $\mathbf{9 5 \%}$ CI & P Value \\
\hline Ceramah & 9,13 & 4,61 & $7,41-10,86$ & 0,001 \\
Diskusi Kelompok & 13,60 & 7,77 & $10,70-16,50$ & \\
Tanpa Perlakuan & 1,07 & 2,27 & $0,22-1,92$ & \\
\hline
\end{tabular}

Hasil uji anova menunjukkan bahwa ada perbedaan bermakna rerata skor selisih pengetahuan di antara ketiga kelompok dengan nilai $\mathrm{P}=0,000$. Untuk melihat kelompok mana saja yang berbeda dilanjutkan dengan uji Tamhane (T2) dengan nilai $\alpha=0,05$. Hasil penelitian menunjukkan bahwa terdapat perbedaan rerata yang bermakna antara kelompok eksperimen I dengan kelompok eksperimen II $(\mathrm{P}=0,028)$. Hal ini menunjukkan adanya pengaruh metode penyuluhan terhadap sikap siswa tentang kesehatan reproduksi remaja, dimana perlakuan penyuluhan dengan metode diskusi kelompok merupakan metode yang mendapat skor tertinggi dengan nilai rerata 13,60.

\section{PEMBAHASAN}

\section{Pengetahuan dan Sikap Responden Sebelum dan Sesudah Dilakukan Penyuluhan \\ 1.1 Pengetahuan Responden Sebelum dan Sesudah Dilakukan Penyuluhan}

Hasil uji anova menunjukkan terdapat perbedaan bermakna selisih skor pengetahuan sebelum dan sesudah perlakuan penyuluhan pada ketiga kelompok dengan nilai $\mathrm{P}=0,001$. Dengan uji lanjut Tamhane (T2) pada a 0,05 diketahui bahwa terdapat perbedaan antara kelompok eksperimen I dengan kelompok eksperimen II $(\mathrm{P}=0,004)$. Nilai rata-rata selisih skor sebelum dan sesudah perlakuan pada kelompok eksperimen $\mathrm{I}=4,03$ dengan standar deviasi 2,14 , kelompok eksperimen $\mathrm{II}=6,30$ dengan standar deviasi 2,96.

\subsection{Sikap Responden Sebelum dan Sesudah Dilakukan Penyuluhan}

Hasil uji anova menunjukkan terdapat perbedaan bermakna selisih skor sikap pada ketiga kelompok dengan nilai $\mathbf{P}=0,001$. Dengan uji lanjut Tamhane (T2) diketahui terdapat perbedaan rerata selisih skor sikap antara kelompok eksperimen I dan kelompok eksperimen II $(\mathrm{P}=0,028)$. Nilai rata-rata selisih skor sikap sebelum dan sesudah perlakuan pada kelompok eksperimen $\mathrm{I}=9,13$ dengan standar deviasi 4,61 dan kelompok eksperimen II $=13,60$ dengan standar deviasi 7,77. Artinya secara statistik menunjukkan ada pengaruh metode penyuluhan terhadap sikap tentang kesehatan reproduksi remaja pada siswa di Yayasan Pendidikan Harapan Mekar Medan, dimana penyuluhan dengan metode diskusi kelompok menunjukkan hasil yang lebih baik dibanding dengan metode ceramah.

Hasil penelitian ini senada dengan penelitian Kustinah (2007) yang menunjukkan bahwa penyuluhan dengan metode ceramah mampu meningkatkan pengetahuan dan sikap siswa tentang kesehatan 
reprodruksi remaja. Penyuluhan dengan metode ceramah mampu meningkatkan pengetahuan siswa di SMU Al-zhar dari skor rerata 8,67 sebelum perlakuan menjadi 11,84 setelah perlakuan dengan uji dependen t-test terdapat pengaruh signifikan dengan nilai $\mathrm{P}=$ 0,001 dan mampu meningkatkan sikap siswa dari skor rerata 9,62 sebelum perlakuan menjadi 14,28 sesudah perlakuan dengan nilai $\mathrm{P}=0,001$.

Veronica (2009) dalam penelitiannya di SMK Pencawan Medan menyebutkan bahwa intervensi penyuluhan dengan metode simulasi dapat menaikkan skor pengetahuan guru tentang kesehatan reproduksi sebesar 2,73 point dan skor sikap guru tentang kesehatan reproduksi sebesar 2,77 point.

Sesuai dengan Konsep Proses Belajar yang dikemukakan oleh Notoatmodjo (1997), penyuluhan yang diberikan menyebabkan terjadinya proses belajar pada responden. Proses belajar ini menghasilkan suatu out put berupa hasil belajar yaitu perubahan pengetahuan dan sikap responden tentang kesehatan reproduksi menjadi lebih baik.

\section{Efektifitas Metode Ceramah dan Diskusi Kelompok Terhadap Peningkatan Pengetahuan dan Sikap Responden}

Alternatif metode yang dapat dipergunakan pada penyuluhan kesehatan reproduksi remaja adalah metode ceramah dan metode diskusi kelompok. Metode ceramah ialah suatu cara penyajian bahan pelajaran dengan melalui penuturan (penjelasan lisan) oleh penyuluh kepada siswa. Metode ceramah, selain sederhana juga efektif dalam upaya penyampaian informasi secara cepat kepada kelompok sasaran yang cukup besar, sedangkan metode diskusi kelompok adalah suatu penyajian bahan pelajaran dengan cara siswa membahas, dengan bertukar pendapat mengenai topik atau masalah tertentu untuk memperoleh suatu pengertian bersama yang lebih jelas dan teliti tentang suatu topik, atau untuk mempersiapkan dan merampungkan keputusan bersama. Metode diskusi kelompok dapat digunakan untuk penyampaian informasi dengan lebih memberikan kesempatan pada siswa untuk mengumpulkan pendapat, membuat kesimpulan atau menyusun berbagai alternatif pemecahan masalah.

Hasil penelitian menunjukkan bahwa kedua metode, baik metode ceramah maupun metode diskusi kelompok berpengaruh terhadap peningkatan skor pengetahuan dan sikap tentang kesehatan reproduksi pada remaja di Yayasan Harapan Mekar Medan, namun metode diskusi kelompok menunjukkan hasil yang lebih efektif dalam meningkatkan pengetahuan dan sikap tentang kesehatan reproduksi remaja dibandingkan dengan metode ceramah. Hal ini terlihat dari rerata selisih skor pengetahuan dan sikap sebelum dan sesudah perlakuan pada kelompok eksperimen II yang mendapat perlakuan penyuluhan dengan metode diskusi kelompok lebih besar dibandingkan dengan rerata selisih skor pengetahuan dan sikap pada kelompok eksperimen I yang mendapat perlakuan penyuluhan dengan metode ceramah. Metode diskusi kelompok meningkatkan skor pengetahuan sebesar $77,49 \%$ dan meningkatkan skor sikap siswa sebesar $20,58 \%$, sedangkan metode ceramah meningkatkan skor pengetahuan siswa sebesar $45,75 \%$ dan skor sikap siswa sebesar $13,22 \%$.

Hasil penelitian ini sesuai dengan teori S-O-R yang dikemukakan oleh Skinner (1953) yang mengungkapkan bahwa perilaku merupakan respons atau reaksi seseorang terhadap stimulus atau rangsangan dari luar, dimana ada dua jenis respons pada individu yaitu respons terbuka berupa praktik atau tindakan dan respons tertutup berupa pengetahuan dan sikap. Perlakuan berupa penyuluhan pada penelitian ini adalah suatu stimulus yang diberikan dengan dua cara yang berbeda, yaitu dengan metode diskusi kelompok dan metode ceramah, hasil penelitian menunjukkan bahwa dengan stimulus yang berbeda akan menimbulkan hasil atau respon yang berbeda pula.

Penyuluhan dengan metode diskusi kelompok memberikan efek yang lebih baik dibandingkan dengan penyuluhan dengan metode ceramah, hal ini dikarenakan metode diskusi kelompok lebih memungkinkan siswa untuk saling bertukar informasi dan mengungkapkan pendapat serta pengalaman sehingga masing-masing siswa lebih banyak mendapat sumber informasi dibanding dengan metode ceramah, dimana pada metode ceramah, komunikasi bersifat satu arah sehingga informasi yang didapat hanya dari fasilitator saja.

\section{KESIMPULAN DAN SARAN}

\section{Kesimpulan}

a. Terdapat perbedaan bermakna rerata selisih skor pengetahuan pada kelompok eksperimen I dan kelompok eksperimen II.

b. Terdapat perbedaan bermakna rerata selisih skor sikap pada kelompok eksperimen I dan kelompok eksperimen II.

c. Metode diskusi kelompok lebih efektif dibanding metode ceramah dalam meningkatkan pengetahuan tentang kesehatan reproduksi pada remaja di Yayasan Pendidikan Harapan Mekar Medan.

d. Metode diskusi kelompok lebih efektif dibanding metode ceramah dalam meningkatkan sikap tentang kesehatan reproduksi pada remaja di Yayasan Pendidikan Harapan Mekar Medan.

e. Tidak terdapat hubungan antara umur, jenis kelamin, sosial ekonomi dan pola asuh dengan pengetahuan dan sikap tentang kesehatan reproduksi pada remaja di Yayasan Pendidikan Harapan Mekar Medan.

\section{Saran}

a. Petugas promosi kesehatan perlu mempertimbangkan metode yang digunakan dalam melakukan kegiatan penyuluhan 
kesehatan agar hasil yang diinginkan dapat tercapai dengan maksimal.

b. Metode diskusi kelompok merupakan salah satu metode yang efektif untuk meningkatkan pengetahuan dan sikap siswa tentang kesehatan reproduksi remaja di Yayasan Pendidikan Harapan Mekar Medan, dianjurkan bagi para petugas promosi kesehatan agar menggunakan metode diskusi kelompok pada kegiatan penyuluhan tentang kesehatan reproduksi remaja.

c. Bagi para peneliti yang tertarik untuk melakukan penelitian sejenis diharapkan dapat melanjutkan penelitian ini dengan menggunakan berbagai metode penyuluhan yang lain sehingga diperoleh metode apa yang paling efektif dalam meningkatkan pengetahuan dan sikap tentang kesehatan reproduksi pada remaja.

d. Bagi pihak sekolah kiranya membuat suatu program penyuluhan pada siswa dengan menggunakan metode diskusi kelompok untuk meningkatkan pengetahuan dan sikap tentang kesehatan reproduksi remaja.

\section{DAFTAR PUSTAKA}

Adrian, 2010. Metode Mengajar Berdasarkan Tipologi Belajar Siswa http://sitimartiah.wordpress.com/2010/01/31/met ode-mengajar-berdasarkan-tipologi-belajarsiswa-oleh-adrian/; diunduh 25 juni 2010.

Arikunto, S., 2000. Manajemen Penelitian, Jakarta : Rineka Cipta.

Azwar, S., 2007. Sikap Manusia ; Teori dan Pengukurannya, Yogyakarta : Pustaka Belajar.

Azwar, Z., 2001. Kesehatan Reproduksi Remaja di Indonesia, Jakarta : Jaringan Epidemiologi Nasional.

Az Zahra, 2010. Genting! Pendidikan Kesehatan ReproduksI : $\quad$ http://mylearningissue. wordpress.com/2010/02/21/gentingpendidikankesehatan-reproduksi/; diunduh 19 Maret 2010.

BKKBN, 2008a . Pendewasaan Usia Perkawinan dan Hakhak Reproduksi bagi Remaja, Jakarta. 2008b. Kurikulum dan Modul Pelatihan Pengelolaan Pusat Informasi dan Konseling Kesehatan Reproduksi Remaja (PIK-KRR), Jakarta.

2008c. Faktor-faktor yang Mempengarui Sikap Terhadap Perilaku Seksual Pra Nikah Pada Remaja di Indonesia : Jurnal Imiah Keluarga Berencana dan Kesehatan Reproduksi, Tahun II, No. 2.

2009. Pergaulan Remaja Makin Mengkhawatirkan : $\quad$ http://sulteng.bkkbn. go.id/old/article detail.php?aid=10; diunduh 14 Februari 2010.

BPS Kota Medan, 2009. Penduduk Menurut Kelompok Umur http://medankota.bps. go.id/?q=content/penduduk-menurut-kelom-pok umur \& destination=node $\% 2 \mathrm{~F} 65$; diunduh 23 Juni 2010.

BPS Sumatera Utara, 2010. Jumlah Penduduk di Bawah Garis Kemiskinan di Sumatera Utara Turun : http://www.indonesia.go.id/id/

index.php?Option=com_content\&task=view\&id $=13025 \&$ Itemid $=851 ;$ diunduh tanggal 21 Agustus 2010.

Chandra, B., 2008. Metodologi Penelitian Kesehatan. Jakarta : EGC.

Dawam, HM, 2009. Keberadaan PIK KRR Makin Urgen : http://www.kulonprogokab. go.id/v2/? pilih=news\&mod ; diunduh 14 Februari 2010.

Depkes RI, 2002. Yang Perlu Diketahui Petugas Kesehatan Tentang Kesehatan Reproduksi, Jakarta.

Dinas Kesehatan Lampung Selatan, 2008. Tinjauan Umum Kesehatan Reproduksi Remaja http://keslamsel.wordpress.com/2008/07/17/ diunduh 1 Maret 2010.

Effendy, N., 1998. Dasar-Dasar Keperawatan Kesehatan Masyarakat, Jakarta : EGC.

Episentrum, 2010. Remaja : http://episentrum.com/artikel/remaja/\#more-213 ; diunduh 1 April 2010.

Ghazali, I., 2002. Aplikasi Analisis Multivariat dengan Program SPSS, Semarang : Universitas Diponegoro.

Harahap, J., 2008. KesehatanReproduksi : http://library.usu.ac.id/download/fk/

kedkomunitas- juliandi.pdf ; diunduh 14 Februari 2010.

Humaidi, N, et.al, 2010. Faktor-Faktor yang Berpengaruh dalam Belajar

http://husamah.staff.umm.ac.id/files/2010/03/MA KALAH-final.pdf : diunduh 06 Juli 2010.

Ikatan Bidan Indonesia, 2000. Kesehatan Reproduksi di Indonesia, Jakarta.

Jameela, A. R., 2008. Remaja Indonesia Masih Sangat Membutuhkan Informasi Kesehatan Reproduksi : http://www.mitrainti. org/?q=node/407 ; diunduh 14 Februari 2010.

Kartono, M., 1998. Kontradiksi Dalam Kesehatan Reproduksi, Jakarta : Pustaka Sinar Harapan.

Kustinah, 2007. Pengaruh Program penyuluhan terhadap Pengetahuan dan Sikap tentang Kesehatan Reproduksi Pada Remaja di SMA Al-Azhar Medan. Tesis Pada Sekolah Pasca Sarjana Universitas Sumatera Utara.

Lemeshow, S.,et.al., 1997. Besar Sampel dalam Penelitian Kesehatan. Alih Bahasa Pramono, D., Yogyakarta : Gajah Mada University Press.

LP3I Unair, 2009. Metode Pembelajaran : http://aula.unair.ac.id/file.php/1/Materi

Pekerti 15-19 Feb.2009/07-Metode Pembelajaran.pdf ; diunduh 21 Mei 2010.

Neutens, J. J., Rubinson,L., 1997. Research Techniques for the Health Sciences, Second Edition, Needham Heights : Viacom Company. 
Notoatmodjo, S., 2002a. Pendidikan Kesehatan dan Ilmu Perilaku, Jakarta : Rineka Cipta. , 2002b. Kesehatan Masyarakat : Ilmu dan Seni, Jakarta : Rineka Cipta. , 2005a. Promosi Kesehatan : Teori dan Aplikasi. Jakarta : Rineka Cipta. , 2005b. Metodologi Penelitian Kesehatan, Jakarta : Rineka Cipta.

Nurlaili, 2009. Metode-metode Pembelajaran : http://www.scribd.com doc/13065635/ Metodemetode-pembelajaran, diunduh $21 \mathrm{Mei}$ 2010.

Panuju, P. et.al, 1999. Psikologi Remaja, Yogyakarta : Tiara Wacana.

Pemko Medan, 2010, Kependudukan : http://www.pemkomedan.go.id/selayang_kepend udukan.php) ; diunduh 22 Februari 2010.

Pinem, S., 2009. Kesehatan Reproduksi \& Kontrasepsi, Jakarta : Trans Info Media.

Pramono, E., 2009, Kesehatan Reproduksi Remaja : http://edypramono-fkmui.blogspot.com/ 2009/04/kesehatan-reproduksi-remaja.html diunduh 14 Februari 2010.

Retnowati, S., 2008. Remaja dan Permasalahannya : Http://sofia-psy.staff.ugm.ac.id/files remaja_dan_permasalahannya.doc ; diunduh 1 April 2010.

Setianingsih, D., 2007. Perbedaan Kedisiplinan Belajar Siswa Ditinjau dari Pola Asuh Orang Tua : Skripsi pada Fakultas Psikologi Universitas Muhammadiyah Surakarta.

Sofa, 2008a. Metode Ceramah dalam Pembelajaran : http://massofa.wordpress.com/2008/07/13 /metode-diskusi-dalam-pembelajaran/ ; diunduh 21 Mei 2010.

2008b. Metode Dikusi dalam Pembelajaran : http://massofa.wordpress.com/2008/07/13/ metode-diskusi-dalam-pembelajaran ; diunduh 21 Mei 2010.

Subarniati, et.al., 2000. Dasar-dasar Pendidikan Kesehatan dan Ilmu Perilaku, Surabaya : Unair.

Subejo, 2008. Pengertian Penyuluhan dan Lingkup Penyuluhan : http://subejo.staff.ugm.ac.id/ wpcontent/gab-luh-hut.pdf; diunduh 14 Februari 2010.
Sudrajat, A., 2008. Pengertian Pendekatan, Strategi, Metode, Teknik, Taktik, dan Model Pembelajaran : http://akhmadsudrajat. wordpress.com/2008/09/12/pengertian-pendekatan-strategi-metode-teknik-taktik-dan-modelpembelajaran/ : diunduh 25 April 2010.

Suliha, U., 2002. Pendidikan Kesehatan dalam Keperawatan, Jakarta : EGC.

Sugiyono, 2001. Metodologi Penelitian Kuantitatif, Kualitatif dan R\&D, Bandung : Alfabeta.

Suparlan, 2007. Diskusi : Metode Mengajar untuk Mengasah Otak, Bukan Otot dan untuk Mengembangkan Sikap Saling Menghormati, Bukan untuk Menang Sendiri: http://www.suparlan.com/pages/ posts/diskusimetode-mengajar-untuk -mengasah-otakbukan- otot-dan-untuk-mengembangkansikap-saling-menghormati- bukan-menangsendiri98.php ; diunduh tanggal 21 Mei 2010.

Surjadi, C., et.al, 2001. Kesehatan Reproduksi Remaja, Ketergantungan Obat dan Kesehatan Kota, Jakarta : Jaringan Epidemiologi Nasional.

Tarmizi, 2010. Pola Asuh Orang Tua dalam Mengarahkan Perilaku Anak : http://esmartschool.co.id/index.php?option=com con tent\&task=view\&id=363\&Itemid=54 diunduh tanggal 01 Juni 2010.

Veronica,J., 2009. Pengaruh Metode Simulasi Terhadap pengetahuan dan Sikap Guru Tentang Pendidikan Kesehatan Reproduksi Remaja di SMU dan SMK Swasta Pencawan Medan. Tesis Pada Sekolah Pasca Sarjana Universitas Sumatera Utara Medan.

Widyastuti, Y., et.al, 2009, Kesehatan Reproduksi. Jakarta : Fitramaya.

Wiknjosasto, G. H.,et.al, 2006. Kesehatan Reproduksi ; Modul Mahasiswa. Jakarta. 